\title{
Comparison among Various Control Methods of Tomato Bacterial Spot Disease (Xanthomonas campestirs pv.vesicatoria)
}

\author{
Frishta F. Abdurrahman \\ Department of Plant
}

*Khalid M. Ahamed

E-mail: Khalid.ahmed@su.edu.krd*

Tahsein A. M. Amein

(Received 24\9\2019; Accepted 19\1\2020)

\section{DOI: $10.33899 /$ rjs.2020.164471}

\begin{abstract}
Two different plant extracts, thyme (Thymus vulgaris) and eucalyptus (Eucalyptus sp.), two bacterial strains, Pseudomonas fluorescens L18 and Bacillus subtilis K3, one antibiotic (Streptomycin) and one bactericide (copper sulphate) were tested for their control efficacy against Tomato Bacterial Spot caused by the bacterium Xanthomonas campestirs pv.vesicatoria under vitro and in vivo conditions.

Two different concentrations of each extract was used, under lab and greenhouse conditions. The eucalyptus extract had better effect than the thyme extract in both conditions. The inhibition zone in Petri dishes was $11.25 \mathrm{~mm}$ and $6.99 \mathrm{~mm}$ and the reduction of disease severity index in plants was $40.7 \%$ and $35.6 \%$ respectively.

The Pseudomonas fluorescens L18 strain had much better and was more effective than the Bacillus subtilis $\mathrm{K} 3$ strain in reduction the disease severity in plants. The disease severity index was reduced by $29.3 \%$ and $18.2 \%$ respectively.

Streptomycin used as antibiotic had a great effect on reduction of the disease severity index $83.5 \%$ and inhibition zone $22.5 \mathrm{~mm}$. Copper sulphate reduced the disease severity index by $87 \%$ and had $38.1 \mathrm{~mm}$ inhibition zone and had the best effect compared with other treatments.
\end{abstract}

Keywords: Xanthomonas campestris pv. vesicatoria, Bacillus subtilisK3, Biological control, Plant extract, Pseudomonas fluorescens. Copper sulphate, Streptomycin

\section{INTRODUCTION}

Tomato (Lycopersicon esculentum Mill.) crop belonging to the family Solanaceae is considered the second economical important crop in all over the world after cereals. It is an economically attractive crop among farmers due to its relatively quick maturity and high yield (Rashid, 2016).

Tomato bacterial spot disease (TBS) caused by Xanthomonas campestris pv. vesicatoria $(\mathrm{Xcv})$ is one of the most important diseases of tomato. Bacterial spot is primarily characterized by appearance of greasy-appearing, water soaked and circular lesions on leaves, stems and fruits with considerable reduction of quality and quantity of tomato yields. (Stall, 1995; Byrnea et al., 2005).

Different methods such as cultural practices, application of chemical pesticides, use of plant extracts, antibiotics and biological agents have been used for controlling the disease (Kucharek, 2000; Morais et al., 2002; Balestra et al., 2009; Varun, 2014).

Several biological agents such as the bacteria Pseudomonas fluorescens, P. putida and Bacillus subtilis, have been used for the disease control under greenhouse and field conditions (El-Hendawy et al., 2005, Abo-Elyousr and El-Hendawy, 2008).

The aim of this study was to evaluate the efficacy of different plant extracts, bacterial strains and antibiotics against the tomato bacterial spot disease in in vitro and in vivo conditions. 


\section{Isolation and Purification of Xcv}

\section{MATERIALS AND METHODS}

Isolation of $\mathrm{Xcv}$ was done from different plant parts (leaves, stems, fruits and seeds). Diseased samples of tomato showing typical symptoms were collected from different locations in Erbil Province during the years $(2015,2016)$. Isolates were identified as Xanthomonas campestirs pv.vesicatoria by standard bacteriological technique, biochemical reaction, molecular method (Polymerase chain reaction) and pathogenicity tests were carried out on tomato fruits and seedlings in order to fulfill the requirements and prove of Koch's postulates.

Pure cultures of Xcv isolated from diseased samples were maintained by subculture.

Culture of the antagonistic bacteria, Pseudomonas fluorescens L18 and Bacillus subtilis K3 Pseudomonas fluorescens L18 and B. subtilis K3 used in this study were isolated from a golf grass and oil- seed rape respectively in Sweden (Amein and Weber, 2002; Tinivella et al., 2009).

\section{Plant Extracts}

\section{Preparation of Plant Extracts}

Plant extracts of thyme and eucalyptus were prepared as follow: Fresh leaves of each plant were washed with sterile distilled water and were dried in the oven at $60{ }^{\circ} \mathrm{C}$ then powdered. Extract of leaves was prepared by mixing $50 \mathrm{~g}$ of powdered materials with $500 \mathrm{ml}$ of $96 \%$ ethanol in Soxhlet extractor for $24 \mathrm{~h}$. at $60{ }^{\circ} \mathrm{C}$. The solution was evaporated to concentrate under reduced pressure and controlled temperature by using rotary evaporator, then dried by using oven at $70{ }^{\circ} \mathrm{C}$. The extracts were weighed and dissolved in dimethyl sulfoxide (DMSO) in order to prepare $100 \mathrm{mg} / \mathrm{ml}$ stock solution of each extract (Valarmathy et al., 2010).

\section{In Vitro Studies}

\section{Screening of Plant Extracts}

The antimicrobial activity of thyme and eucalyptus extracts were tested in in vitro (Bacterial growth inhibition test). Three different concentrations of extracts i.e., (5, 10 and 20\%) were prepared. $(0.1 \mathrm{ml})$ of $X c v$ bacterial suspension $\left(1 \times 10^{8} / \mathrm{ml}, 48 \mathrm{~h}\right.$ old culture) were spread onto NA plate medium with saturated and sterilized cotton buds. Six $\mathrm{mm}$ in diameter well was punched in each agar plate with the help of sterilized Cork borer. 50,100 and $200 \mu \mathrm{l}$ of each plant extracts at each concentration $(5,10,20 \%)$ were added to the wells individually by using a micropipette. The inoculated agar plates were left for one hour for proper diffusion then plates were incubated at 26$28{ }^{\circ} \mathrm{C}$ for $72 \mathrm{~h}$. Dimethyl sulfoxide (DMSO) was used as negative control for each extract. Antibacterial activities of each concentrate were measured in form of inhibition zones in $\mathrm{mm}$ surrounding the punchers. Each assay was performed in five replicates and mean values were reported (Morais et al., 2002 and Parekh and Chanda, 2007).

\section{Biological Agents}

Two bacterial strains ( $P$. fluorescence and B. subtilis) were used in this study. The method used was as above except that instead of plant extracts, bacterial suspension $\left(1 \times 10^{8} \mathrm{cfu} / \mathrm{ml}, 48 \mathrm{~h}\right.$ old culture) were used. Diameter of inhibition zone was measured as described by (Boudyach et al., 2001).

Antibiotics

The antibiotics used in this study were streptomycin, with concentration $(0.3 \mathrm{mg} / \mathrm{ml})$ and Copper based compounds (copper sulphate) with concentration of (19\%). The method used was as above for plant extracts. Effect of tested antibiotics were measured in form of inhibition zone surrounding the punchers according to (Loo et al., 1945).

\section{In vivo Study}

This experiment was conducted to evaluate the efficacy of different compounds (Thyme and eucalyptus extracts, $P$. fluorescens and B.subtillus strains, streptomycin and copper sulphate) in reduction of the bacterial spot disease in tomato caused by $X c v$.

In all in vivo studies, pots $(13 \mathrm{~cm}$ diameter and $14 \mathrm{~cm}$ deep) containing one $\mathrm{kg}$ sterilized commercial peat mixture / pot, were planted with one seedling/pot (4 week old) of 122-321 oval 
Cocktail tomato cultivar. Each treatment had nine replicates. The same amount of plants (pots) not treated (healthy) were used as control.

Symptoms and disease severity were recorded after 12 -14 days from inoculation. Inoculated plants were kept on a greenhouse bench and rated for foliar bacterial spot disease using the following scale: $1=$ symptomless, $2=$ a few necrotic spots on a few leaflets, $3=$ a few necrotic spots on many leaflets, $4=$ many spots with coalescence on few leaflets, $5=$ many spots with coalescence on many leaflets, $6=$ severe disease and leaf defoliation, and $7=$ plant dead (Abbasii et al., 2002).

A disease severity index (DSI) was calculated using the following formula:

\section{DSI $(\%)=\sum$ (class $x$ no. of plants in class) $\quad \times 100$ \\ Total no. of plants $x($ no. of classes -1$)$}

Five $\mathrm{ml}$ of each Thyme and eucalyptus plant extract at $20 \%$ concentration, the two bacterial strains $P$. fluorescence and B. subtillus, streptomycin $(0.3 \mathrm{mg} / \mathrm{ml})$ and (copper sulphate) $23 \%$ concentration were sprayed individually on plant leaves one day after tomato seedlings inoculation with the $X c v$ bacterial suspension and maintenance in a humid chamber for $24 \mathrm{~h}$. Disease incidence and severity were recorded, after 12 - 14 days. Pots spread with $X c v$ only were served as a positive control and only spread with water served as negative control.

\section{Statistical Analysis}

For interpretation of data, analysis of variance (ANOVA) was used, with sources and amounts of variation compared using an $X c v$ ratio test. To compare treatment means, Duncan's test at $\leq$ p 0.05 were calculated. Means followed by different letters demonstrated a significant difference.

\section{In vitro}

\section{Plant extract}

The test results showed that eucalyptus leaves extract was more effective than thyme leaves in inhibiting the bacterial growth in laboratory condition. Also results revealed that, all tested concentrations of extracts had good inhibitory effect on growth of the $X c v$ bacteria compared with the control Fig. (1). Increasing the concentration increased gradually the inhibition zone. The best effect with $11.25 \mathrm{~mm}$ inhibition zone had the $20 \%$ concentration of eucalyptus extract. $10 \%$ of eucalyptus extract had $(8.74 \mathrm{~mm})$ better and significantly affect than $20 \%$ thyme extract $(6.99 \mathrm{~mm})$. Both extracts in all concentrations inhibited the pathogen growth in Petri dishes.

Santos and Waterman (2001a); Santos and Waterman (2001b); De vincenzi et al., (2002); Mustafa and Yeşim, (2005) and Rosato et al., (2007) reported that eucalyptus and thyme antibacterial extracts have a great effect on reducing the disease severity. The obtained results are also in harmony with those reported by Morais et al., (2002) who tested the antimicrobial activity of 45 extracts of medicinal plants against $X . c$. pv. vesicatoria. Besides, the obtained findings of Basim et al., (2006) confirmed the antimicrobial effect of plant extracts against $X c v$ where they screened the effect of aqueous extracts from leaves of 30 higher plants, in vitro for their antibacterial activity against different pathovars of $X c v$ bacterium. Eight plant species showed antibacterial activity, based on the inhibition zone in a diffusion assay. This concept is currently more flexible, and various compounds that are considered resistance inducers also exert direct action on the pathogens. Active compounds of the extract act directly on the pathogens or induce host resistance through the production of phytoalexins, increased PRP activity, synthesis of structural compounds, and biochemical plant defense (Mustafa and Yeşim, 2005). 


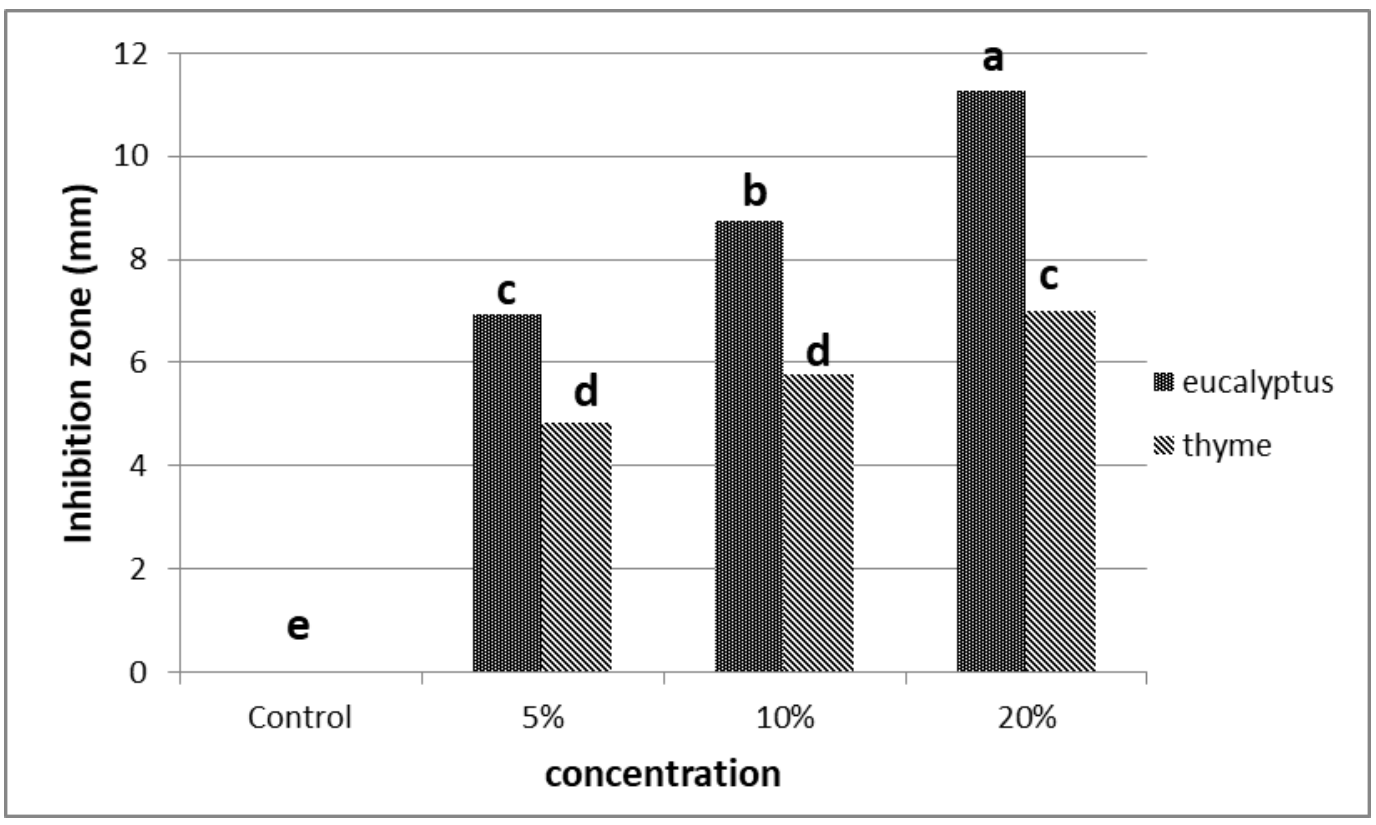

Fig. 1: Effects of eucalyptus and thyme plant extracts on $X c v$ inhibition zone based on Duncan's multiple.

*Column followed by the different letter are significantly different at $P<0.05$

\section{Effect of Bioagents:}

Pseudomonas fluorescens and B. subtilis strains were tested for their abilities to inhibit the growth of $X c v$ on nutrient agar (NA) medium. None of the two bacterial strains had positive effect on the growth of the pathogen and the inhibition zone was zero $\mathrm{mm}$. The results disagree with Sahin et al., (2000). They reported the good antagonistic effect of these strains against Xcv. Treatments had significant effect in reduction the disease. Different strains of $P$. fluorescens and many other Xanthomonas pathovars had clear inhibitory effects on $X c v$ under in vitro conditions (Campbell, et al., 1998).

\section{Antibiotics:}

The data results in Fig. (2) indicate that both tested antibiotics had an inhibitory effect on the growth of the pathogenic bacteria compared with the control. Copper sulphate had better inhibition zone $(29.7 \mathrm{~mm})$ than the streptomycin with $(26 \mathrm{~mm})$ but this difference was not significant. These two treatments were better than all other treatments in laboratory condition. Similar results were obtained by Carrillo-Fasio et al., (2001); Roberto et al., (2002); Martin and Hamilton, (2004) and Shukla and Gupta, (2004). They all reported inhibition zones and reduction in diameter of bacterial growth when treated with streptomycin and copper based bactericides. Also, Carrillo-Fasio et al., (2001) tested thirty nine X.cv strains for their sensitivity to several copper formulations and combinations of copper + mancozeb, copper + antibiotics, in laboratory and field experiments. 


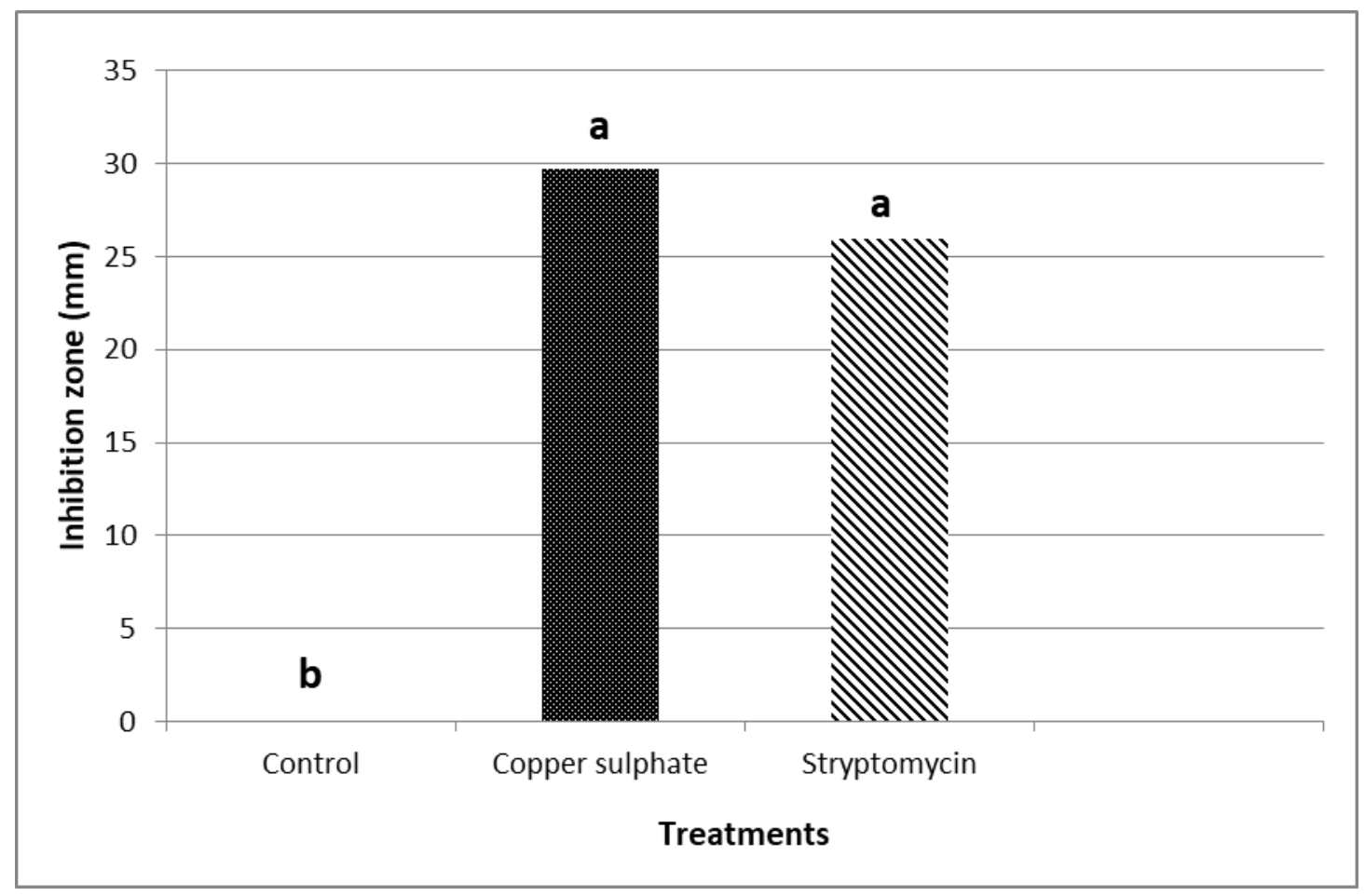

Fig.2: Effects of Streptomycin and the Copper sulphate on the growth of Xcv on NA medium based on Duncan's multiple.

Column followed by the different letter are significantly different at $P<0.05$

\section{Greenhouse Experiment:}

The results presented in Fig. (3) Shows that all treatments (plant extracts, bioagents, antibiotics and bactericide) were effective in controlling bacterial spot disease on tomato leaves. All treatments significantly reduced the disease severity of foliar disease in greenhouse conditions. The bactericide and the antibiotic were the most effective in reducing the disease severity with $83.5 \%$ and $79.4 \%$ respectively compared with the untreated control. The Eucalyptus extract reduced disease severity by $40.7 \%$ and the Thyme extract by $35.6 \%$. Lucas et al., (2012) mentioned that plant extracts and essential oils have significant role in reducing the disease.

The Pseudomonas strain reduced the disease severity by $29.3 \%$ and the Bacillus strain only by $18.2 \%$. The results by Moustaine et al., 2019, showed that the bacterial strain Pantoea agglomerans reduced $70 \%$ of the onset of disease symptoms, bacterial canker of tomato incited by Clavibacter michiganensis spp michiganensis Serratia proteamaculans $45 \%$ and Bacillus cereus $75 \%$. Significant variations in reduction of disease incidence, enhancement in plant growth and yield were observed in tomato plants treated with these PGPR strains as compared to the control. Aureobasidium pullulans and Pantoea agglomerans the two strains also were able to inhibit, in vitro, the growth of $C$. michiganensis subsp. Michiganensis and their antagonistic effects were confirmed in greenhouse conditions (El kinany et al., 2017).

Copper and antibiotic results are in agreement with Jones et al., (1991a, b); Stall, (1995) who stated that copper formulations proved there effect in reduction bacterial spot development. The chemical control has been extensively used for controlling bacterial spot diseases because copper based formulations are capable of inhibiting or delaying bacterial cell multiplications and could reduce losses. But, chemical sprays often are not very effective in long time, because their extensive use led to the development of copper resistant strains (Kousik and Ritchie, 1996; Teixeira et al., 2008; Nisa et al., 2010). Disease management practices, based primarily on fixed copper bactericides, do not give consistent, effective protection (Abbasi et al., 2002). They reported that foliar applications of ammonium lignosulfonate (ALS), and the fertilizer potassium phosphate (KP) 
tested for their ability to control this disease under both greenhouse and field conditions do not significantly increased total tomato or pepper yield.

Behki and Khan, (2001) and Aguiar et al., (2003) mentioned that resistance is widespread in Xcv in several geographical regions, where copper was not effective for disease control. Loo et al., (1945); Roberts et al., (2008) and Kizheva et al., (2013) stated that streptomycin is also effective against the tomato bacteria spot pathogen.

Hasan et al., (2005) stated that plant extracts have played significant role in reducing the incidence of seed-borne pathogens and in the improvement of seed quality and emergence of plant seeds in the field. Both bacterial strains had the less effect in controlling the disease.

Our results are in agreement with Tzeng et al., (1994); Byrnea et al., 2005; Abo-Elyousr and El-Hendawy, (2008) and Walters, (2009). All of them mentioned that biological control provided good protection against the disease in small-scale plots. For example P. fluorescens gave promising inhibitory effects, while their results are disagree with Ali, (2011) who stated that biological control is not comprehensively practiced.

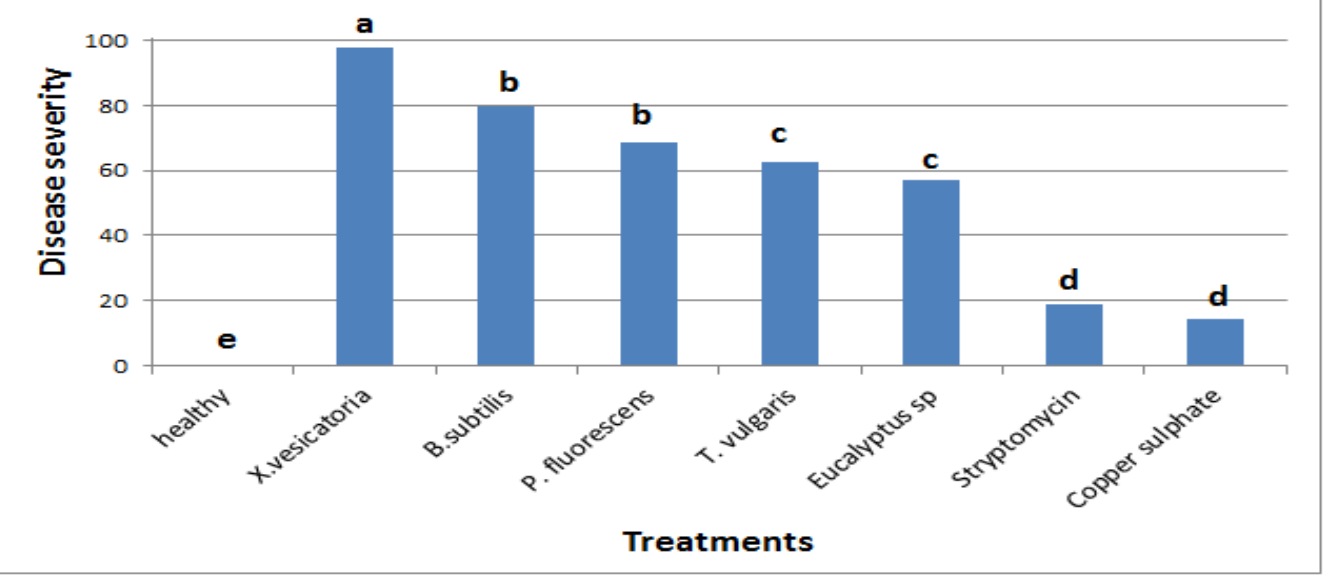

Fig 3: Effects of plant extracts, bacterial strains, antibiotic and bactericide on tomato bacteria spot disease reduction under greenhouse condition based on Duncan's multiple.

* Column followed by the different letter is significantly different at $P<0.05$

\section{REFERENCES}

Abbasii, P.A.; Soltani, N.; Cuppels, D.A.; Lazarovits, G. (2002). Reduction of bacterial spot disease severity on tomato and pepper plants with foliar applications of ammonium lignosulfonate or potassium phosphate. Plant Dis. 86,1232-1236..

Abo-Elyousr, K.A.M.; El-Hendawy, H.H. (2008). Integration of Pseudomonas fluorescens and Acibenzolar-S-methyl to control bacterial spot disease of tomato. Crop Protection, 27(7), 1118-1124.

Aguiar, L; Kimura, O.; Castilho, A.M.C.; Castilho, K.S.C.; Ribeiro, R.L.D.; Akiba, F.; Carmo, M.G.F. (2003). Efeito de formulações cúpricase cuprorgânicas na severidade da manchabacterianae na população de Xanthomonas campestris pv. vesicatoria empimentão. Horticultura Brasileira, 21,44-50. (Portgalian, English Abstract).

Ali, E.O.H. (2011). Biological and chemical control of bacterial diseases infecting tomato plants. PhD Thesis, Agricultural Sciences (Plant Pathology), Fac. Agric. Moshtohor, Zagazig University.166p.

Amein, T.; Weber, Z. (2002). Seed treatment with strains of Pseudomonas fluorescens as potential bio control agents of wheat take all. J. Plant Dis. and Protection., 109, 655- 661. 
Balestra, G.M.; Heydari, A.; Ceccarelli, D.; Ovidi, E.; Quattrucci, A. (2009). Antibacterial effect of Allium sativum and Ficus carica extracts on tomato bacterial pathogens. Crop Protection, 28, 807-811.

Basim, E., Basim, H. ; Özcan, M. (2006). Antibacterial activities of Turkish pollen and propolis extracts against plant bacterial pathogens. J. Food Engineering., 77(4),992-996.

Behki, R.; Khan, S.U. (2001). Impact of long term application of atrazine on soil properties and bound residues formation, Proceedings IAEA, 1248, 37-42.

Boudyach, E.H.; Fatmi, M.; Akhayat, O.; Benizri, E.; Ben Aoumar, A.A. (2001). Selection of antagonistic bacteria of Clavibacter michiganensis subsp. michiganensis and evaluation of their efficiency against bacterial canker of tomato. Bioco. Sci. Technol., 11(1), 141-149.

Byrnea, J.M.; Dianesea, A.C.; JI, P.; Campbell, H.L.; Cuppels, D.A.; Louws, F.J.; Miller, S.A.; Jonce, J.B.; Wilsona, M. H.(2005). Biological control of bacterial spot of tomato under Weld conditions at several locations in North America. Biol. Control., 32, 408-418.

Carrillo-Fasio, J.A.; Sanchez-Bautista, L.; Garcia-Estrada, R.S.; ALlende-Molar, R.; MarquezZequera, I. (2001). Races of Xanthomonas campestris pv. vesicatoria (Doidge) Dye. Present in the State of Sinaloa. Mexico. Revista Mexicana de Fitopatologia, 19(2), 248250.

Campbell, L.; Moss, B.; Byrne, J.; Dianese, A.; Wolson, M. (1998). The good, the bad, and the ugly: biocontrol of bacterial spot of tomato. Alabama-Agricultural-experimental-station, 45(2), 8-10.

De vinceczi, M.; Silano, M.; De vinceczi,, A.; Maialetti, F.; Scazzocchi, B. (2002). Constituents of aromatic plants: eucalyptol. Phytoterapia, 73, 269-275.

El-Hendawy, H.H.; Mohamed, E.O.; Noha, M.S. (2005) Biological control of bacterial spot of tomato caused by Xanthomonas campestris pv. vesicatoria by Rahnella aquatilis. Microbiol. Res., 160, 343-352.

El kinany, S.; Haggoud, A.; Benbouaza A.; Bouaichi, A.; El Hassan, A. (2017). Plant growth promotion and bacterial canker control of Lycopersicon esculentum L. cv. Campbell 33 by biocontrol agents. J. Crop Prot., 6 (2), 235-244

Hasan, M.M.; Chowdhury, S.P.; Hossain, B.; Alam, M.S. (2005). Antifungal effects of plant extracts on seed-borne fungi of wheat seed regarding seed germination, seedling health and vigor index. Pakistan J. Biol. Sci., 8(9), 1284-1289.

Jones, J.B.; Woltz, S.S.; Jones J.P.; Portier, K.L. (1991a). Population dynamics of Xanthomonas campestris pv. vesicatoria on tomato leaflets treated with copper bactericides. Phytopathol., 81, 714-719.

Jones, J.B.; Woltz, S.S.; Kelly, R.O. ; HAarris, G. (1991b). The role of ionic copper, total copper and select bactericides on control of bacterial spot of tomato. Proceedings of the Florida State Hort. Soci., 104, 257-259.

Kizheva, Y.; Vancheva, T.; Hristova, P.; Stoyanova, M.; Stojanovska, M.; Moncheva, P.; Bogatzevska, N. (2013). Identification of Xanthomonas strains from tomato and pepper and their sensitivity to antibiotics and copper. Bulg. J. Agric. Sci., Supplement., 2(19),8082.

Kousik, C.S.; Ritchie, D.F. (1996). Race shift in Xanthomonas campestris pv. vesicatoria within a season in field-grown pepper. Phytopathol., 86,952.

Kucharek, T. (2000). "Bacterial Spot of Tomato and Pepper". Florida Cooperative Extension Service/Institute of Food and Agricultural Sciences, University of Florida, Gainesville, Plant Pathology Fact Sheet. pp.2-3.

Loo, Y.H.; Skell, P.S.; Thornberry, H.H.; Ehrlick, J.; Mcguire, J.H.; Savage, J.H.; Sylvester, J.C. (1945). Assay of streptomycin by paper-disc plate method. J. Bacteriol., 50, 709-710.

Lucas, G.C.; Alves, E; Pereira, R.B.; Perina, F.G.; Desouza, R.M. (2012). Antibacterial activity of essential oils on Xanthomonas vesicatoria and control of bacterial spot in tomato. Brasília., 47(3), 351-359. 
Martin, H.L.; Hamilton, V.A. (2004). Copper tolerance in Australian populations of Xanthomonas campestris $p v$. vesicatoria contributes to poor field control of bacterial spot of pepper. Plant Dis., 88, 921-924.

Moustaine, M.; El Kahkahi, R.; Benbouazza, A.; Benkirane, R.; El Hassan, A.(2019). Potential of biological treatments for control of bacterial canker of tomato incited by Clavibacter michiganensis spp michiganensis in Morocco. Eurasia J. Bio. Sci., 13, 1481-1488.

Morais, L.A.S.; Carmo, M.G.F.; Viegas, E.C.; Teixeira, D.F.; Barreto, A.S.; Pizarro, A.P.B.; Gilbert, B. (2002). Evaluation of antimicrobial activity of extracts of medicinal plants on three tomato phytopathogens. Acta Hort., 569,87-90

Mustafa, M.; Yesim, A. (2005). Effect of some plant extracts as seed treatments on bacterial spot disease of tomato and pepper. J. Turk. Phytopathol., 34(1-3), 9-16.

Nisa, P.; Sirikan, N.; Sarinya, B.; Nisanart, C.; Skorn, M.; Paiboon, V. (2010). Copper ions potentiate organic hydroperoxide and hydrogen peroxide toxicity through different mechanisms in Xanthomonas campestrispv.campestris. FEMS Microbiol. Letters., 313(1), $75-80$

Parekh, J.; Chanda, S. (2007). In vitro antimicrobial activity and phytochemical analysis of some Indian medicinal plants. Turkish J. Biol., 31(1), 53-58.

Rashid, T.S. (2016). Antimicrobial activity of Rhus coriaria L. fruit extracts against selected bacterial and fungal pathogens on tomato. PhD Dissertation, University of Putra Malaysia: $143 \mathrm{p}$.

Roberto, B.; Luciano, S.; Mery, F.; Paola, S.; Angelo, B. (2002). Induction of systemic acquired resistance in pepper plants by Acibenzolar-S-methyl against bacterial spot disease. European J. Plant Pathol., 108, 41-49.

Roberts, P.D.; Momol, M.T.; Ritchie, L.; Olson, S.M.; Jones, J.B.; Balogh, B. (2008). Evaluation of spray programs containing famoxadone plus cymoxanil, Acibenzolar-Smethyl, and Bacillus subtilis compared to copper sprays for management of bacterial spot on tomato. Crop Protection, 27, 1519-1526.

Rosato, A.; Vitali, C.; Delaurentis, N.; Armenise, D.; Antoniettamilillo, M.( 2007). Antibacterial effect of some essential oils administered alone or in combination with Norfloxacin. Phytomedicine, 14, 727-732.

Sahin, F.; Kotan, R.; Demirci, E.; Miller, S.A. (2000). Effects of Actigard and some antagonists in biological control of bacterial spot disease on tomato and pepper. Ziraat Fakuumalutltesi Dergisi, 31(1)11-16.

Santos, C.S.; Watermam, P.G. (2001a). Polyphenols from Eucalyptus consideniana and Eucalyptus viminalis. Fitoterapia., 72,95-97.

Santos, C.S.; Watermam, P.G. (2001b). Polyphenols from Eucalyptus ovata. Fitoterapia., 72,316318.

Shukla, A.; Gupta, S.K. (2004). Management of bacterial spot (Xanthomonas campestris pv. vesicatoria) through chemicals. J. Myco. Plant Pathol., 34(1),88-90.

Stall, R.E.; Beaulieu, C.; Egel, G.; Hodge, N.C.; Leite, R.P.; Minsavage, G.V.; Bouzar, H.; Jones, J.B.; Alvarez, A.M. ; Benedict, A.A. (1994). Two genetically diverse groups of strains are included in Xanthomonas campestris pv. vesicatoria. International J. Sys. Bacteriol., 44, 47-53.

Stall, R.E. (1995). Xanthomonas campestris pv. vesicatoria. In: U.S. Singh, R.P. Singh, and K. Kohmoto (Eds). Pathogenesis and host specificity in plant diseases: histopathological, biochemical, genetic and mol. bases. Elsevier Sci., New York. pp. 167-181.

Teixeira, E.C.; Oliveira, J.C.F.; Novo, M.T.M.; Bertolini, M.C. (2008). The copper resistance operon cop.AB from Xanthomonas axonopodis pathovar citri: gene inactivation results in copper sensitivity. J. Microbiol., 154,402-412. 
Tinivella, F.; Hirata, L.M.; Celan, A.; Wright, S.A.I.; Amein, T.; Schmitt, A. (2009). Control of seed-borne pathogens on legumes by microbial and other alternative seed treatments. Euro. J. Plant Pathol., 123, 139-151.

Tzeng, K.C.; LIN, Y.C. ; Hsu, S.T. (1994). Foliar fluorescent pseudomonads from crops in Taiwan and their antagonism to phytopathogenic bacteria. Plant Pathol. Bull., 3(1), 24-33.

Valarmathy, K.; Gokulakrishnan, M.; Kausar, M.S.; Paul, K. (2010) A study of antimicrobial activity of ethanolic extracts of various plant leaves against selected microbial species. International J. Pharma Sci. and Res., 1(8), 293-295.

Varun, K. (2014). Screening of Euphorbia hirta for antibacterial activity against plant pathogens. MSc. Thesis, Faculty of Technology Anna University.70p.

Walters, Dale R. (2009). Are plants in the field already induced: Implications for practical disease control. Crop Protection., 28 (6),459-465.

\title{
طرائق مكافحة مرض التبقع البكتيري للطماطة المتسبب عن البكتيريا
}

\section{Xanthomonas campestirs pv.vesicatoria.}

\author{
الملخص \\ تم استخدام مستخلصين نباتيين، اوراق الزعتر (Thymus vulgaris) واليوكاليبتوس (Eucalyptus sp.) ) و سلالنين

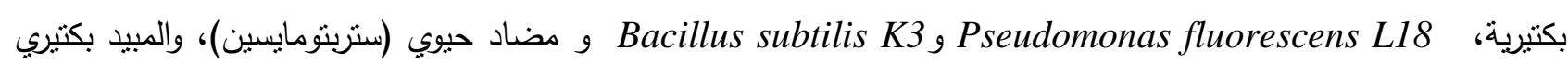

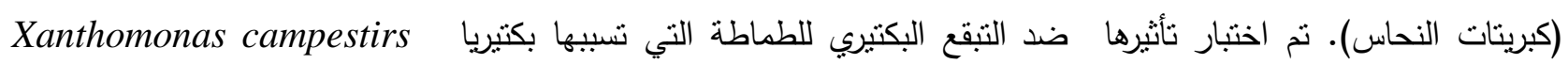 \\ pv.vesicatoria. \\ تم استخدام تركيزين مختلفين لكل مستخلص تحت ظروف المختبر والحقل. كان لمستخلص البوكالبتوس نأثير أفضل من \\ مستخلص الزعتر في كلتا الحالتين. كان منطقة التثبط 11.25 ملم و 6.99 ملم و انخفاض مؤشر شدة المرض كان 40.7 ٪ 4.6 \\ و 35.6\% على التوالي. \\ كانت سلالة Pl fluorescens L18 أفضل بكثير وكانت أكثر نشاطًا من سلالة B. subtilis K3 في تقليل شدة \\ المرض. خفضت هذه السلالات مؤشر شدة المرض بنسبة 29.3 ٪ و 18.2 \% على التوالي.

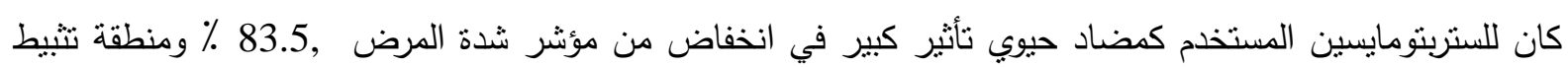

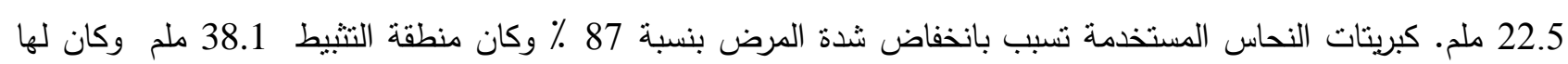 \\ أفضل ثأثثر مقارنة مع الطرق الأخرى.
}

